\title{
Patterns in COVID-19 Vaccination Coverage, by Social Vulnerability and Urbanicity — United States, December 14, 2020-May 1, 2021
}

\begin{abstract}
Vaughn Barry, PhD ${ }^{1,2, *}$; Sharoda Dasgupta, PhD ${ }^{2, *}$; Daniel L. Weller, $\mathrm{PhD}^{2}$; Jennifer L. Kriss, $\mathrm{PhD}^{2}$; Betsy L. Cadwell, $\mathrm{MSPH}^{2}$; Charles Rose, PhD²; Cassandra Pingali, MPH, MS²; Trieste Musial, MS ${ }^{2,3}$; J. Danielle Sharpe, MS 3 ; Stephen A. Flores, PhD ${ }^{2}$; Kurt J. Greenlund, PhD ${ }^{4}$; Anita Patel, PharmD ${ }^{2}$; Andrea Stewart, $\mathrm{PhD}^{2}$; Judith R. Qualters, $\mathrm{PhD}^{2}$; LaTreace Harris, $\mathrm{MPH}^{2}$; Kamil E. Barbour, $\mathrm{PhD}^{2}$; Carla L. Black, PhD ${ }^{2}$
\end{abstract}

\section{On May 28, 2021, this report was posted as an MMWR Early Release on the MMWR website (https://www.cdc.gov/mmwr).}

Disparities in vaccination coverage by social vulnerability, defined as social and structural factors associated with adverse health outcomes, were noted during the first 2.5 months of the U.S. COVID-19 vaccination campaign, which began during mid-December 2020 (1). As vaccine eligibility and availability continue to expand, assuring equitable coverage for disproportionately affected communities remains a priority. CDC examined COVID-19 vaccine administration and 2018 CDC social vulnerability index (SVI) data to ascertain whether inequities in COVID-19 vaccination coverage with respect to county-level SVI have persisted, overall and by urbanicity. Vaccination coverage was defined as the number of persons aged $\geq 18$ years (adults) who had received $\geq 1$ dose of any Food and Drug Administration (FDA)-authorized COVID-19 vaccine divided by the total adult population in a specified SVI category. ${ }^{\dagger}$ SVI was examined overall and by its four themes (socioeconomic status, household composition and disability, racial/ethnic minority status and language, and housing type and transportation). Counties were categorized into SVI quartiles, in which quartile 1 (Q1) represented the lowest level of vulnerability and quartile 4 (Q4), the highest. Trends in vaccination coverage were assessed by SVI quartile and urbanicity, which was categorized as large central metropolitan, large fringe metropolitan (areas surrounding large cities, e.g., suburban), medium and small metropolitan, and nonmetropolitan counties. ${ }^{\S}$ During December 14, 2020-May 1, 2021, disparities in vaccination coverage by SVI increased, especially in large

\footnotetext{
*These authors contributed equally to this report.

$\dagger$ Vaccination coverage was calculated by summing the number of vaccinated adults in each SVI category and dividing by the total adult population in the specified SVI category. Population denominators were obtained from the U.S. Census Bureau.

$\$$ Urbanicity was defined on the basis of the 2013 National Center for Health Statistics urban-rural classification scheme. For this analysis, categories included large central metropolitan counties, large fringe metropolitan counties, medium and small metropolitan counties, and nonmetropolitan counties. Large central metropolitan counties are counties in metropolitan statistical areas (MSAs) with $\geq 1$ million population; large fringe metropolitan counties are counties in MSAs with $\geq 1$ million population that did not qualify as large central metropolitan counties; medium metropolitan counties are counties in MSAs with populations of 250,000-999,999; small metropolitan counties are counties in MSAs with populations $<250,000$; nonmetropolitan counties are all micropolitan and noncore counties. https://www.cdc.gov/nchs/data_access/urban_rural.htm
}

fringe metropolitan (e.g., suburban) and nonmetropolitan counties. By May 1, 2021, vaccination coverage was lower among adults living in counties with the highest overall SVI; differences were most pronounced in large fringe metropolitan ( $Q 4$ coverage $=45.0 \%$ versus $Q 1$ coverage $=61.7 \%$ ) and nonmetropolitan $(\mathrm{Q} 4=40.6 \%$ versus $\mathrm{Q} 1=52.9 \%)$ counties. Vaccination coverage disparities were largest for two SVI themes: socioeconomic status (Q4 $=44.3 \%$ versus Q1 $=61.0 \%)$ and household composition and disability (Q4 $=42.0 \%$ versus $Q 1=60.1 \%$ ). Outreach efforts, including expanding public health messaging tailored to local populations and increasing vaccination access, could help increase vaccination coverage in high-SVI counties.

COVID-19 vaccination data are reported to CDC through state, local, and territorial immunization information systems, the Vaccine Administration Management System, or direct data submission to the CDC Data Clearinghouse. County-level data on FDA-authorized COVID-19 vaccines administered during December 14, 2020-May 1, 2021, and reported through May 5, 2021, were analyzed. County-level SVI data were obtained from the 2018 CDC SVI, which is used to prioritize public health resources for communities with the greatest needs during and following emergencies $(2,3)$. Ranked scores ranging from $0-1$ were created for all 3,142 U.S. counties based on 15 population-based social determinants of health measures, categorized into one of four themes: socioeconomic status, household composition and disability, racial/ethnic minority status and language, and housing type and transportation. ${ }^{* *}$ Scores for overall SVI and themes were analyzed as quartiles. The 15 individual SVI components were dichotomized at the median, based on distribution among all U.S. counties. County urbanicity was categorized as large central metropolitan, large fringe metropolitan, medium and small metropolitan, and nonmetropolitan.

Data from adults living in 3,129 (99\%) U.S. counties were analyzed; California counties with populations $<20,000$ and all Hawaii counties were excluded because of lack of available county-level vaccination data. Vaccine recipients were categorized by SVI metrics and urbanicity, based on

\footnotetext{
Entities including jurisdictions, pharmacies, and federal agencies reported vaccinations to CDC. A cloud-hosted data repository received, deduplicated, and deidentified vaccination data. https://www.cdc.gov/coronavirus/2019-ncov/ vaccines/distributing/about-vaccine-data.html
} 
county of residence. Trends in vaccination coverage were evaluated by epidemiologic week for SVI quartile, stratified by urbanicity. Generalized estimating equation models using binomial regression and an identity link were used to estimate vaccination coverage by SVI metrics, overall and by urbanicity. ${ }^{\dagger \dagger}$ Absolute coverage differences with corresponding 95\% confidence intervals (CIs) were calculated to evaluate differences between groups. Differences in coverage by SVI were also evaluated for three separate periods to assess variation in inequities over time. ${ }^{\$ \$}$ All analyses were conducted using SAS (version 9.4; SAS Institute). This activity was reviewed by CDC and was conducted consistent with applicable federal law and CDC policy. 99

During December 14, 2020-May 1, 2021, 54\% of adults living in the 3,129 assessed U.S. counties received $\geq 1$ dose of COVID-19 vaccine. Disparities in vaccination coverage by SVI increased over time, especially in large fringe metropolitan and nonmetropolitan counties, where coverage differences between SVI Q4 and Q1 counties were most prominent (Figure) (Supplementary Table, https://stacks.cdc.gov/view/ cdc/106461).

By May 1, 2021, after states opened eligibility to all adults, vaccination coverage was lower among adults living in counties with the highest overall SVI $(\mathrm{Q} 4$ coverage $=49.0 \%$ versus $\mathrm{Q} 1$ coverage $=59.3 \%)$ (Table 1). Coverage differences between adults living in counties with the highest versus lowest SVI were $-11.0 \%$ $(95 \% \mathrm{CI}=-13.2 \%$ to $-8.9 \%)$ in large central metropolitan

\footnotetext{
** The 15 population-based social factors incorporated into the SVI measures included 1) percentage of persons with incomes below poverty threshold, 2) percentage of civilian population (aged $\geq 16$ years) that is unemployed, 3) per capita income, 4) percentage of persons aged $\geq 25$ years with no high school diploma, 5) percentage of persons aged $\geq 65$ years, 6) percentage of persons aged $\leq 17$ years, 7) percentage of civilian noninstitutionalized population aged $>5$ years with a disability, 8) percentage of single-parent households with children aged $<18$ years, 9) percentage of persons who are racial/ethnic minorities (i.e., all persons except those who are non-Hispanic White), 10) percentage of persons aged $\geq 5$ years who speak English "less than well," 11) percentage of housing in structures with $\geq 10$ units (multiunit housing), 12) percentage of housing structures that are mobile homes, 13) percentage of households with more persons than rooms (crowding), 14) percentage of households with no vehicle available, and 15) percentage of persons living in institutionalized group quarters. Estimates were created using 2014-2018 (5-year) data from the American Community Survey (https://www.atsdr.cdc.gov/placeandhealth/svi/documentation/pdf/ SVI2018Documentation-H.pdf). The 15 indicators are categorized into four themes: 1) socioeconomic status (indicators 1-4), 2) household composition and disability (indicators 5-8), 3) racial/ethnic minority status and language (indicators 9 and 10), and 4) housing type and transportation (indicators 11-15). Overall SVI includes all 15 indicators as a composite measure. https://www. atsdr.cdc.gov/placeandhealth/svi/fact_sheet/fact_sheet.html

$\dagger^{\dagger} 95 \% \mathrm{CIs}$ for the vaccination coverage differences used robust standard errors to account for state variability.

$\$ \$$ Periods used in the Supplementary Table were December 14, 2020-January 23, 2021; January 24-March 20, 2021; and March 21-May 1, 2021.

9945 C.F.R. part 46, 21 C.F.R. part 56; 42 U.S.C. Sect. 241(d); 5 U.S.C. Sect. 552a; 44 U.S.C. Sect. 3501 et seq.
}

\section{Summary}

What is already known about this topic?

Counties with higher levels of social vulnerability have been disproportionately affected by COVID-19.

What is added by this report?

Disparities in county-level vaccination coverage by social vulnerability have increased as vaccine eligibility has expanded, especially in large fringe metropolitan (areas surrounding large cities, e.g., suburban) and nonmetropolitan counties. By May 1, 2021, vaccination coverage among adults was lower among those living in counties with lower socioeconomic status and with higher percentages of households with children, single parents, and persons with disabilities.

What are the implications for public health practice?

Outreach efforts, including expanding public health messaging tailored to local populations and increasing vaccination access, could help increase vaccination coverage in counties with high social vulnerability.

counties, $-16.7 \%(95 \% \mathrm{CI}=-20.7 \%$ to $-12.7 \%)$ in large fringe metropolitan counties, $-8.2 \%(95 \% \mathrm{CI}=-13.1 \%$ to $-3.4 \%)$ in medium and small metropolitan counties, and $-12.3 \%$ $(95 \% \mathrm{CI}=-16.4 \%$ to $-8.2 \%)$ in nonmetropolitan counties. Coverage differed by three SVI themes: coverage was lower in counties with higher SVI pertaining to socioeconomic status (Q4 $=44.3 \%$ versus Q1 $=61.0 \%)$ and household composition and disability $(\mathrm{Q} 4=42.0 \%$ versus $\mathrm{Q} 1=60.1 \%)$, but higher in counties with higher SVI related to racial and ethnic minority residents and English proficiency ( $\mathrm{Q} 4=56.5 \%$ versus $\mathrm{Q} 1=45.3 \%)$.

Individual components of SVI themes related to socioeconomic status and housing composition and disability highlighted factors contributing to disparities. Vaccination coverage was lower among adults living in counties with per capita income less than the median (42.7\%) compared with those in counties at or above the median $(56.7 \%)$ and other social determinants of poor health, including poverty and less education, especially in large fringe metropolitan and nonmetropolitan counties (Table 2). Vaccination coverage was also lower among adults living in counties where the percentages of children, persons with disabilities, or singleparent households were at or above the median $(51.3 \%, 43.9 \%$, and $51.5 \%$, respectively) compared with those in counties where the percentages of these groups were below the median $(56.8 \%$, $56.3 \%$, and $58.0 \%$, respectively), especially in large fringe metropolitan counties. Although coverage did not vary by the SVI theme related to housing type and transportation, one component of this theme suggested disparities in coverage. Specifically, vaccination coverage was lower in counties where the percentage of mobile homes was at or above the median (42.1\%) compared with those where this percentage was below the median $(58.8 \%)$. 
FIGURE. COVID-19 vaccination coverage among U.S. adults, by county social vulnerability index quartile* and urbanicity ${ }^{\dagger}\left(\mathrm{N}=3,129\right.$ counties $\left.{ }^{\S}\right)-$ United States, December 14, 2020-May 1, $2021^{\uparrow, * *}$
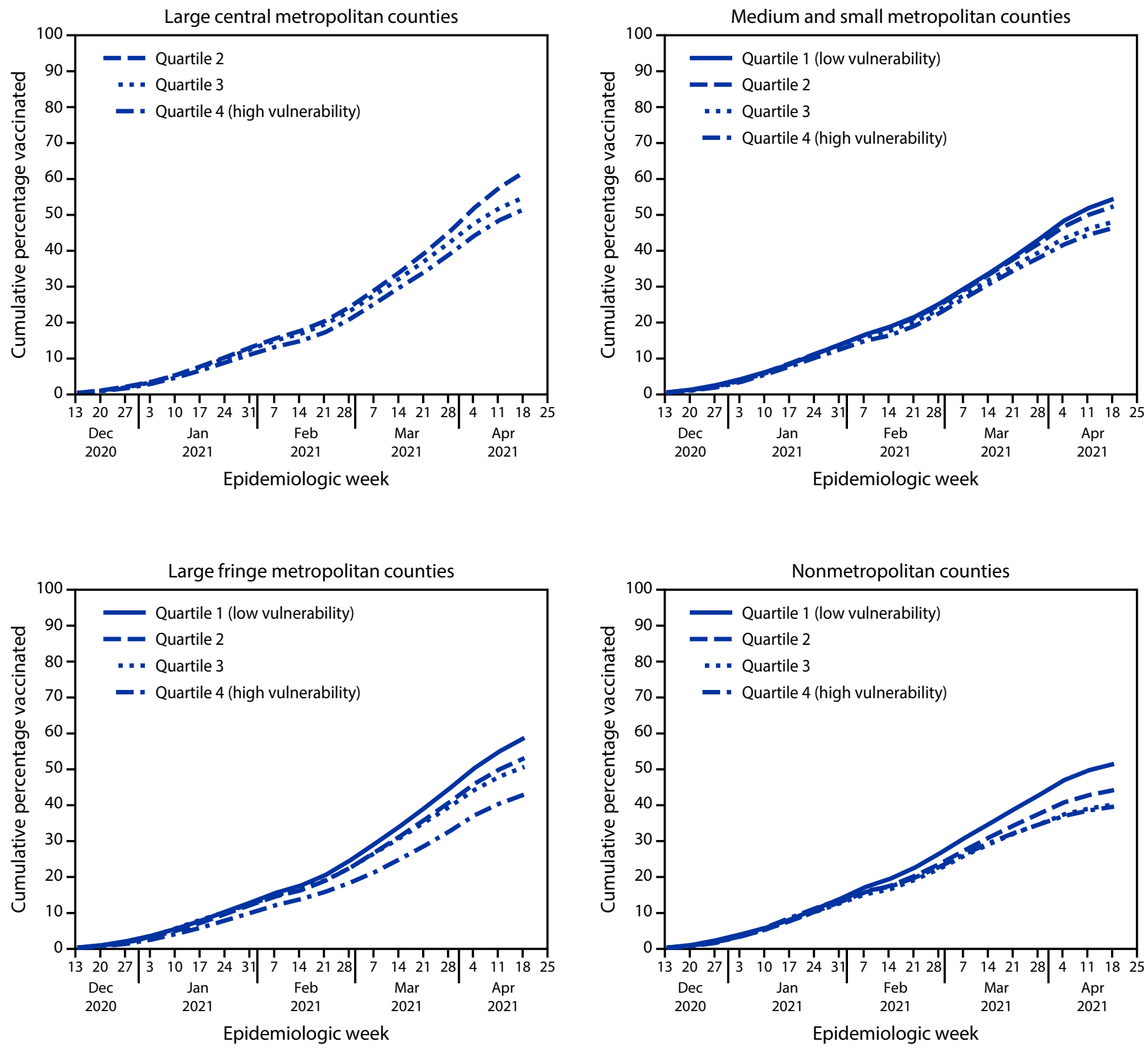

Abbreviation: $\mathrm{SVI}=$ social vulnerability index.

* Scores for all SVI measures represented percentile rankings by county, ranging from 0-1, with higher scores indicating higher vulnerability. Scores were categorized into quartiles based on distribution among all 3,142 U.S. counties and then applied to the 3,129 assessed counties.

† Urbanicity categories were based on the 2013 National Center for Health Statistics urban-rural classification scheme (https://www.cdc.gov/nchs/data/series/sr_02/ sr02_166.pdf). Categories were collapsed into large metropolitan, large fringe metropolitan, medium and small metropolitan, and nonmetropolitan (micropolitan and noncore) counties.

$\S$ California counties with populations $<20,000(n=8)$ and all Hawaii counties $(n=5)$ were excluded because of lack of available county-level vaccination data.

१ Only 6 days of data were available for week December 13, 2020 (analysis used data from December 14, 2020, and on).

** Results were suppressed for SVI and urbanicity categories with four or fewer counties (quartile 1, large central metropolitan counties). 
TABLE 1. Associations between social vulnerability index* and vaccination coverage ${ }^{\dagger}$ among U.S. adults, overall and by county urbanicity ${ }^{\S}$ $\left(\mathrm{N}=3,129\right.$ counties $\left.^{\natural}\right)$ - United States, December 14, 2020-May 1, 2021

\begin{tabular}{|c|c|c|c|c|c|c|c|c|c|c|}
\hline \multirow[b]{3}{*}{$\begin{array}{l}\text { SVI } \\
\text { quartile }\end{array}$} & \multirow{2}{*}{\multicolumn{2}{|c|}{$\begin{array}{c}\text { All } \\
\text { counties } \\
(\mathrm{N}=3,129) \\
\end{array}$}} & \multirow{2}{*}{\multicolumn{2}{|c|}{$\begin{array}{c}\begin{array}{c}\text { Large central } \\
\text { metropolitan }\end{array} \\
(n=68)\end{array}$}} & \multirow{2}{*}{\multicolumn{2}{|c|}{$\begin{array}{c}\begin{array}{c}\text { Large fringe } \\
\text { metropolitan }\end{array} \\
(n=368) \\
\end{array}$}} & \multirow{2}{*}{\multicolumn{2}{|c|}{$\begin{array}{c}\begin{array}{c}\text { Medium and small } \\
\text { metropolitan }\end{array} \\
(n=727) \\
\end{array}$}} & \multicolumn{2}{|c|}{ Nonmetropolitan } \\
\hline & & & & & & & & & & $(n=1,966)$ \\
\hline & $\begin{array}{c}\mathrm{VC} \\
\text { estimate }\end{array}$ & $\begin{array}{c}\text { VC differences } \\
(95 \% \mathrm{Cl})\end{array}$ & $\begin{array}{c}\text { VC } \\
\text { estimate }\end{array}$ & $\begin{array}{l}\text { VC differences } \\
(95 \% \mathrm{Cl})\end{array}$ & $\begin{array}{c}\text { VC } \\
\text { estimate }\end{array}$ & $\begin{array}{l}\text { VC differences } \\
(95 \% \mathrm{Cl})\end{array}$ & $\begin{array}{c}\text { VC } \\
\text { estimate }\end{array}$ & $\begin{array}{l}\text { VC differences } \\
(95 \% \mathrm{Cl})\end{array}$ & $\begin{array}{c}\text { VC } \\
\text { estimate }\end{array}$ & $\begin{array}{l}\text { VC differences } \\
(95 \% \mathrm{Cl})\end{array}$ \\
\hline \multicolumn{11}{|l|}{ Overall SVI } \\
\hline Q1 (lowest) & 59.3 & Ref & - ${ }^{* *}$ & - & 61.7 & Ref & 56.2 & Ref & 52.9 & Ref \\
\hline Q2 & 56.0 & $\begin{array}{r}-3.2 \\
(-7.2 \text { to } 0.8)\end{array}$ & 65.1 & Ref & 55.6 & $\begin{array}{r}-6.1 \\
(-10.2 \text { to }-2.0)\end{array}$ & 54.1 & $\begin{array}{r}-2.1 \\
(-5.9 \text { to } 1.7)\end{array}$ & 45.4 & $\begin{array}{r}-7.5 \\
(-10.6 \text { to }-4.5)\end{array}$ \\
\hline Q3 & 52.5 & $\begin{array}{r}-6.8 \\
(-10.3 \text { to }-3.3)\end{array}$ & 57.4 & $\begin{array}{r}-7.7 \\
(-11.9 \text { to }-3.5)\end{array}$ & 53.1 & $\begin{array}{r}-8.6 \\
(-11.7 \text { to }-5.5)\end{array}$ & 49.5 & $\begin{array}{r}-6.7 \\
(-10.5 \text { to }-2.9)\end{array}$ & 41.3 & $\begin{array}{r}-11.6 \\
(-15.4 \text { to }-7.9)\end{array}$ \\
\hline Q4 (highest) & 49.0 & $\begin{array}{r}-10.3 \\
(-14.1 \text { to }-6.4)\end{array}$ & 54.0 & $\begin{array}{r}-11.0 \\
(-13.2 \text { to }-8.9)\end{array}$ & 45.0 & $\begin{array}{r}-16.7 \\
(-20.7 \text { to }-12.7)\end{array}$ & 47.9 & $\begin{array}{r}-8.2 \\
(-13.1 \text { to }-3.4)\end{array}$ & 40.6 & $\begin{array}{r}-12.3 \\
(-16.4 \text { to }-8.2)\end{array}$ \\
\hline \multicolumn{11}{|c|}{ SVI related to socioeconomic status } \\
\hline Q1 (lowest) & 61.0 & Ref & - & - & 62.2 & Ref & 57.1 & Ref & 54.7 & Ref \\
\hline Q2 & 54.2 & $\begin{array}{r}-6.8 \\
(-9.6 \text { to }-4.0)\end{array}$ & 59.2 & Ref & 51.7 & $\begin{array}{r}-10.5 \\
(-13.5 \text { to }-7.4)\end{array}$ & 52.9 & $\begin{array}{r}-4.2 \\
(-7.0 \text { to }-1.5)\end{array}$ & 46.8 & $\begin{array}{r}-7.9 \\
(-11.1 \text { to }-4.6)\end{array}$ \\
\hline Q3 & 50.0 & $\begin{array}{r}-11.0 \\
(-13.4 \text { to }-8.6)\end{array}$ & 55.2 & $\begin{array}{r}-4.0 \\
(-10.6 \text { to } 2.6)\end{array}$ & 45.0 & $\begin{array}{r}-17.1 \\
(-21.0 \text { to }-13.3)\end{array}$ & 46.4 & $\begin{array}{r}-10.7 \\
(-14.1 \text { to }-7.4)\end{array}$ & 40.9 & $\begin{array}{r}-13.8 \\
(-17.7 \text { to }-9.9)\end{array}$ \\
\hline Q4 (highest) & 44.3 & $\begin{array}{r}-16.7 \\
(-20.9 \text { to }-12.5)\end{array}$ & 50.8 & $\begin{array}{r}-8.5 \\
(-17.3 \text { to } 0.4)\end{array}$ & 41.4 & $\begin{array}{r}-20.8 \\
(-26.9 \text { to }-14.6)\end{array}$ & 48.4 & $\begin{array}{r}-8.7 \\
(-16.2 \text { to }-1.1)\end{array}$ & 39.2 & $\begin{array}{r}-15.5 \\
(-19.7 \text { to }-11.3)\end{array}$ \\
\hline \multicolumn{11}{|c|}{ SVI related to household composition and disability } \\
\hline Q1 (lowest) & 60.1 & Ref & - & - & 61.5 & Ref & 56.5 & Ref & 50.0 & Ref \\
\hline Q2 & 50.1 & $\begin{array}{r}-10.0 \\
(-12.6 \text { to }-7.3)\end{array}$ & 51.7 & Ref & 48.6 & $\begin{array}{r}-12.8 \\
(-15.7 \text { to }-10.0)\end{array}$ & 51.5 & $\begin{array}{r}-4.9 \\
(-7.8 \text { to }-2.0)\end{array}$ & 45.3 & $\begin{array}{r}-4.7 \\
(-7.9 \text { to }-1.6)\end{array}$ \\
\hline Q3 & 47.5 & $\begin{array}{r}-12.6 \\
(-15.2 \text { to }-9.9)\end{array}$ & 52.8 & $\begin{array}{r}1.1 \\
(-1.8 \text { to } 4.1)\end{array}$ & 44.5 & $\begin{array}{r}-17.0 \\
(-22.7 \text { to }-11.3)\end{array}$ & 48.6 & $\begin{array}{r}-7.9 \\
(-10.8 \text { to }-5.0)\end{array}$ & 42.9 & $\begin{array}{r}-7.1 \\
(-10.5 \text { to }-3.7)\end{array}$ \\
\hline Q4 (highest) & 42.0 & $\begin{array}{r}-18.1 \\
(-21.1 \text { to }-15)\end{array}$ & 47.7 & $\begin{array}{r}-4.0 \\
(-6.0 \text { to }-2.1)\end{array}$ & 37.3 & $\begin{array}{r}-24.2 \\
(-27.9 \text { to }-20.5)\end{array}$ & 42.2 & $\begin{array}{r}-14.2 \\
(-17.1 \text { to }-11.3)\end{array}$ & 41.0 & $\begin{array}{r}-9.0 \\
(-12.8 \text { to }-5.2)\end{array}$ \\
\hline \multicolumn{11}{|c|}{ SVI related to racial and ethnic minority residents and English proficiency } \\
\hline Q1 (lowest) & 45.3 & Ref & - & - & 48.7 & Ref & 46.5 & Ref & 43.9 & Ref \\
\hline Q2 & 47.4 & $\begin{array}{r}2.1 \\
(-1.2 \text { to } 5.3)\end{array}$ & - & - & 52.9 & $\begin{array}{r}4.3 \\
(-2.2 \text { to } 10.7)\end{array}$ & 46.2 & $\begin{array}{r}-0.3 \\
(-5.1 \text { to } 4.6)\end{array}$ & 45.3 & $\begin{array}{r}1.4 \\
(-1.9 \text { to } 4.6)\end{array}$ \\
\hline Q3 & 51.6 & $\begin{array}{r}6.3 \\
(2.0 \text { to } 10.5)\end{array}$ & 61.0 & Ref & 55.4 & $\begin{array}{r}6.7 \\
\text { (2.5 to } 10.9 \text { ) }\end{array}$ & 51.5 & $\begin{array}{r}5.1 \\
(-1.8 \text { to } 11.9)\end{array}$ & 43.4 & $\begin{array}{r}-0.5 \\
(-4.9 \text { to } 3.8)\end{array}$ \\
\hline Q4 (highest) & 56.5 & $\begin{array}{r}11.2 \\
\text { (6.4 to } 15.9 \text { ) }\end{array}$ & 57.9 & $\begin{array}{r}-3.2 \\
(-9.9 \text { to } 3.5)\end{array}$ & 59.1 & $\begin{array}{r}10.4 \\
\text { (4.1 to } 16.7 \text { ) }\end{array}$ & 53.3 & $\begin{array}{r}6.8 \\
(-0.3 \text { to } 14.0)\end{array}$ & 43.6 & $\begin{array}{r}-0.4 \\
(-5.7 \text { to } 5.0)\end{array}$ \\
\hline \multicolumn{11}{|c|}{ SVI related to housing type and transportation } \\
\hline Q1 (lowest) & 53.2 & Ref & - & - & 55.7 & Ref & 47.8 & Ref & 47.2 & Ref \\
\hline Q2 & 52.7 & $\begin{array}{r}-0.5 \\
(-3.9 \text { to } 2.9)\end{array}$ & 54.4 & Ref & 58.4 & $\begin{array}{r}2.8 \\
(-2.0 \text { to } 7.5)\end{array}$ & 50.0 & $\begin{array}{r}2.2 \\
(-2.8 \text { to } 7.2)\end{array}$ & 44.5 & $\begin{array}{r}-2.7 \\
(-5.5 \text { to } 0.2)\end{array}$ \\
\hline Q3 & 53.4 & $\begin{array}{r}0.2 \\
(-3.4 \text { to } 3.9)\end{array}$ & 54.9 & $\begin{array}{r}0.4 \\
(-5.8 \text { to } 6.7)\end{array}$ & 58.2 & $\begin{array}{r}2.5 \\
(-1.8 \text { to } 6.9)\end{array}$ & 52.6 & $\begin{array}{r}4.8 \\
(0.0 \text { to } 9.6)\end{array}$ & 43.5 & $\begin{array}{r}-3.7 \\
(-6.2 \text { to }-1.1)\end{array}$ \\
\hline Q4 (highest) & 55.1 & $\begin{array}{r}1.9 \\
(-2.2 \text { to } 5.9)\end{array}$ & 60.2 & $\begin{array}{r}5.8 \\
(-1.0 \text { to } 12.6)\end{array}$ & 56.1 & $\begin{array}{r}0.4 \\
(-7.4 \text { to } 8.2)\end{array}$ & 51.6 & $\begin{array}{r}3.8 \\
(-1.2 \text { to } 8.8)\end{array}$ & 43.0 & $\begin{array}{r}-4.2 \\
(-7.7 \text { to }-0.7)\end{array}$ \\
\hline
\end{tabular}

Abbreviations: $\mathrm{Cl}$ = confidence interval; Ref = referent group; $\mathrm{SVI}=$ social vulnerability index; $\mathrm{VC}=$ vaccination coverage.

* Scores for all SVI measures represent percentile ranks by county ranging from 0-1 with higher scores indicating higher vulnerability. Scores were categorized into quartiles based on distribution among all 3,142 U.S. counties and then applied to the 3,129 assessed counties.

+ Vaccination coverage ( $\geq 1$ dose) was calculated by summing the number of vaccinated adults in each SVI category and dividing by the total adult population in the specified SVI category. $95 \%$ Cls for the vaccination coverage differences were calculated using generalized estimating equation models with robust standard errors to account for state variability.

§ Urbanicity categories were based on the 2013 National Center for Health Statistics urban-rural classification scheme (https://www.cdc.gov/nchs/data/series/sr_02/ sr02_166.pdf). Categories were collapsed into large metropolitan, large fringe metropolitan, medium and small metropolitan, and nonmetropolitan (micropolitan and noncore) counties.

I California counties with populations $<20,000(n=8)$ and all Hawaii counties $(n=5)$ were excluded because of lack of available county-level vaccination data.

** Results were suppressed for SVI and urbanicity categories with four or fewer counties; reference group was the lowest vulnerability quartile with more than four counties.

\section{Discussion}

Counties with higher SVIs have been disproportionately affected by the COVID-19 pandemic (4); therefore, ensuring equitable access to COVID-19 vaccination is a priority for the U.S. COVID-19 vaccination program (5). In addition, disparities in vaccination coverage by SVI have increased over time, especially in large fringe metropolitan and nonmetropolitan counties. Disparities were associated with county-level differences in socioeconomic status and household composition and disability. Although disparities were not associated with 
TABLE 2. Associations between individual components of the social vulnerability index ${ }^{*}$ and vaccination coverage ${ }^{\dagger}$ among U.S. adults, overall and by urbanicity ${ }^{\S}\left(N=3,129\right.$ counties $\left.^{\natural}\right)$ - United States, December 14, 2020-May 1, 2021

\begin{tabular}{|c|c|c|c|c|c|c|c|c|c|c|}
\hline \multirow[b]{3}{*}{$\begin{array}{l}\text { SVI } \\
\text { indicator }\end{array}$} & \multirow{2}{*}{\multicolumn{2}{|c|}{$\begin{array}{c}\begin{array}{c}\text { All } \\
\text { counties }\end{array} \\
(N=3,129)\end{array}$}} & \multirow{2}{*}{\multicolumn{2}{|c|}{$\begin{array}{c}\begin{array}{l}\text { Large central } \\
\text { metropolitan }\end{array} \\
(n=68)\end{array}$}} & \multirow{2}{*}{\multicolumn{2}{|c|}{$\begin{array}{c}\begin{array}{c}\text { Large fringe } \\
\text { metropolitan }\end{array} \\
(n=368)\end{array}$}} & \multirow{2}{*}{\multicolumn{2}{|c|}{$\begin{array}{c}\begin{array}{c}\text { Medium and small } \\
\text { metropolitan }\end{array} \\
(n=727)\end{array}$}} & \multirow{2}{*}{\multicolumn{2}{|c|}{$\begin{array}{c}\text { Nonmetropolitan } \\
(n=1,966)\end{array}$}} \\
\hline & & & & & & & & & & \\
\hline & $\begin{array}{c}\text { VC } \\
\text { estimate }\end{array}$ & $\begin{array}{c}\text { VC differences } \\
(95 \% \mathrm{CI})\end{array}$ & $\begin{array}{c}\text { VC } \\
\text { estimate }\end{array}$ & $\begin{array}{l}\text { VC differences } \\
(95 \% \mathrm{Cl})\end{array}$ & $\begin{array}{c}\text { VC } \\
\text { estimate }\end{array}$ & $\begin{array}{l}\text { VC differences } \\
(95 \% \mathrm{Cl})\end{array}$ & $\begin{array}{c}\text { VC } \\
\text { estimate }\end{array}$ & $\begin{array}{c}\text { VC differences } \\
(95 \% \mathrm{Cl})\end{array}$ & $\begin{array}{c}\text { VC } \\
\text { estimate }\end{array}$ & $\begin{array}{c}\text { VC differences } \\
(95 \% \mathrm{Cl})\end{array}$ \\
\hline \multicolumn{11}{|c|}{ SVI related to socioeconomic status } \\
\hline \multicolumn{11}{|c|}{ Percentage of persons living below poverty (median $=14.7 \%$ ) } \\
\hline Below median & 57.4 & Ref & 63.9 & Ref & 58.5 & Ref & 54.4 & Ref & 49.1 & Ref \\
\hline At or above median & 49.8 & $\begin{array}{r}-7.7 \\
(-10.0 \text { to }-5.3)\end{array}$ & 54.8 & $\begin{array}{r}-9.1 \\
(-15.3 \text { to }-2.9)\end{array}$ & 45.9 & $\begin{array}{r}-12.7 \\
(-15.6 \text { to }-9.7)\end{array}$ & 48.6 & $\begin{array}{r}-5.8 \\
(-8.9 \text { to }-2.7)\end{array}$ & 40.8 & $\begin{array}{r}-8.3 \\
(-11.2 \text { to }-5.5)\end{array}$ \\
\hline \multicolumn{11}{|c|}{ Percentage of persons unemployed $($ median $=5.4 \%)$} \\
\hline Below median & 56.6 & Ref & 61.4 & Ref & 60.0 & Ref & 53.3 & Ref & 47.0 & Ref \\
\hline At or above median & 51.9 & $\begin{array}{r}-4.7 \\
(-6.7 \text { to }-2.7)\end{array}$ & 56.5 & $\begin{array}{r}-4.9 \\
(-8.6 \text { to }-1.1)\end{array}$ & 52.9 & $\begin{array}{r}-7.1 \\
(-9.8 \text { to }-4.4)\end{array}$ & 50.4 & $\begin{array}{r}-3.0 \\
(-5.9 \text { to } 0.0)\end{array}$ & 42.0 & $\begin{array}{r}-5.0 \\
(-7.8 \text { to }-2.3)\end{array}$ \\
\hline \multicolumn{11}{|c|}{ Income per capita (median $=\$ 26,245)$} \\
\hline At or above median & 56.7 & Ref & 一** & - & 58.6 & Ref & 53.9 & Ref & 50.9 & Ref \\
\hline Below median & 42.7 & $\begin{array}{r}-14 \\
(-16.5 \text { to }-11.5)\end{array}$ & - & - & 41.6 & $\begin{array}{r}-16.9 \\
(-20.7 \text { to }-13.2)\end{array}$ & 45.1 & $\begin{array}{r}-8.8 \\
(-12.4 \text { to }-5.2)\end{array}$ & 40.2 & $\begin{array}{r}-10.7 \\
(-13.3 \text { to }-8.2)\end{array}$ \\
\hline \multicolumn{11}{|c|}{ Percentage of persons aged $\geq 25$ years with no high school diploma (median $=12.1 \%$ ) } \\
\hline Below median & 56.5 & Ref & 60.1 & Ref & 59.4 & Ref & 53.7 & Ref & 49.9 & Ref \\
\hline At or above median & 50.4 & $\begin{array}{r}-6.2 \\
(-9.2 \text { to }-3.1)\end{array}$ & 56.8 & $\begin{array}{r}-3.3 \\
(-7.5 \text { to } 1.0)\end{array}$ & 47.6 & $\begin{array}{r}-11.8 \\
(-15.4 \text { to }-8.3)\end{array}$ & 47.1 & $\begin{array}{r}-6.5 \\
(-10.8 \text { to }-2.3)\end{array}$ & 39.8 & $\begin{array}{r}-10.2 \\
(-12.7 \text { to }-7.6)\end{array}$ \\
\hline \multicolumn{11}{|c|}{ SVI related to household composition and disability } \\
\hline \multicolumn{11}{|c|}{ Percentage of persons aged $\geq 65$ years $($ median $=18 \%$ ) } \\
\hline Below median & 54.9 & Ref & 57.9 & Ref & 57.5 & Ref & 51.7 & Ref & 42.8 & Ref \\
\hline At or above median & 49.4 & $\begin{array}{r}-5.5 \\
(-8.1 \text { to }-3.0)\end{array}$ & 61.0 & $\begin{array}{r}3.1 \\
(-5.3 \text { to } 11.5)\end{array}$ & 54.9 & $\begin{array}{r}-2.5 \\
(-6.7 \text { to } 1.7)\end{array}$ & 50.6 & $\begin{array}{r}-1.1 \\
(-4.1 \text { to } 1.9)\end{array}$ & 45.2 & $\begin{array}{r}2.4 \\
(-0.1 \text { to } 4.9)\end{array}$ \\
\hline \multicolumn{11}{|c|}{ Percentage of persons aged $<18$ years $($ median $=22.3 \%)$} \\
\hline Below median & 56.8 & Ref & 63.1 & Ref & 60.7 & Ref & 53.6 & Ref & 45.8 & Ref \\
\hline At or above median & 51.3 & $\begin{array}{r}-5.5 \\
(-7.8 \text { to }-3.3)\end{array}$ & 53.3 & $\begin{array}{r}-9.7 \\
(-11.4 \text { to }-8.1)\end{array}$ & 54.8 & $\begin{array}{r}-6.0 \\
(-11.0 \text { to }-0.9)\end{array}$ & 49.6 & $\begin{array}{r}-4 \\
(-6.4 \text { to }-1.7)\end{array}$ & 42.1 & $\begin{array}{r}-3.7 \\
(-6.2 \text { to }-1.3)\end{array}$ \\
\hline \multicolumn{11}{|c|}{ Percentage of persons living with a disability (median $=15.4 \%$ ) } \\
\hline Below median & 56.3 & Ref & 58.2 & Ref & 58.1 & Ref & 53.8 & Ref & 47.7 & Ref \\
\hline At or above median & 43.9 & $\begin{array}{r}-12.4 \\
(-15.1 \text { to }-9.7)\end{array}$ & 51.7 & $\begin{array}{r}-6.5 \\
(-12.3 \text { to }-0.8)\end{array}$ & 43.7 & $\begin{array}{r}-14.4 \\
(-19.2 \text { to }-9.6)\end{array}$ & 44.7 & $\begin{array}{r}-9.1 \\
(-12.3 \text { to }-5.8)\end{array}$ & 42.0 & $\begin{array}{r}-5.7 \\
(-8.4 \text { to }-3.0)\end{array}$ \\
\hline \multicolumn{11}{|c|}{ Percentage of households with single parents and children (median $=8.1 \%$ ) } \\
\hline Below median & 58.0 & Ref & 65.3 & Ref & 62.4 & Ref & 54.7 & Ref & 45.5 & Ref \\
\hline At or above median & 51.5 & $\begin{array}{r}-6.5 \\
(-8.3 \text { to }-4.6)\end{array}$ & 55.7 & $\begin{array}{r}-9.6 \\
(-11.6 \text { to }-7.6)\end{array}$ & 51.5 & $\begin{array}{r}-10.9 \\
(-13.8 \text { to }-8.0)\end{array}$ & 49.9 & $\begin{array}{r}-4.8 \\
(-7.3 \text { to }-2.3)\end{array}$ & 43.0 & $\begin{array}{r}-2.4 \\
(-4.7 \text { to }-0.1)\end{array}$ \\
\hline \multicolumn{11}{|c|}{ SVI related to racial and ethnic minority residents and English proficiency } \\
\hline \multicolumn{11}{|c|}{ Percentage of racial and ethnic minority residents (median $=16.1 \%)$} \\
\hline Below median & 48.5 & Ref & - & - & 53.7 & Ref & 49.2 & Ref & 45.1 & Ref \\
\hline At or above median & 55.1 & $\begin{array}{r}6.6 \\
(3.2 \text { to } 10.1)\end{array}$ & - & - & 57.9 & $\begin{array}{r}4.2 \\
(0.5 \text { to } 7.9)\end{array}$ & 52.1 & $\begin{array}{r}2.9 \\
(-1.1 \text { to } 6.9)\end{array}$ & 42.9 & $\begin{array}{r}-2.2 \\
(-5.9 \text { to } 1.4)\end{array}$ \\
\hline \multicolumn{11}{|c|}{ Percentage of persons who speak English less than well (median $=0.7 \%$ ) } \\
\hline Below median & 45.8 & Ref & - & - & 50.3 & Ref & 45.7 & Ref & 43.9 & Ref \\
\hline At or above median & 55.2 & $\begin{array}{r}9.5 \\
(6.4 \text { to } 12.5 \text { ) }\end{array}$ & - & - & 58.1 & $\begin{array}{r}7.7 \\
\text { (4.4 to } 11.1 \text { ) }\end{array}$ & 52.5 & $\begin{array}{r}6.8 \\
(3.4 \text { to } 10.2 \text { ) }\end{array}$ & 44.3 & $\begin{array}{r}0.4 \\
(-2.5 \text { to } 3.3)\end{array}$ \\
\hline \multicolumn{11}{|c|}{ SVI related to housing type and transportation } \\
\hline \multicolumn{11}{|c|}{ Percentage of housing structures with $\geq 10$ units (median $=2.9 \%$ ) } \\
\hline Below median & 40.9 & Ref & - & - & 40.7 & Ref & 42.3 & Ref & 40.4 & Ref \\
\hline At or above median & 55.4 & $\begin{array}{r}14.5 \\
(11.9 \text { to } 17.1)\end{array}$ & - & - & 58.3 & $\begin{array}{r}17.7 \\
(14.8 \text { to } 20.6)\end{array}$ & 52.2 & $\begin{array}{r}9.9 \\
\text { (5.9 to } 13.9 \text { ) }\end{array}$ & 47.4 & $\begin{array}{r}7.0 \\
\text { (5.0 to } 8.9 \text { ) }\end{array}$ \\
\hline Percentage of housi & ing units $t$ & that are mobile $h$ & e units & edian $=10.9 \%$ & & & & & & \\
\hline Below median & 56.4 & Ref & - & - & 58.8 & Ref & 53.6 & Ref & 49.7 & Ref \\
\hline At or above median & 42.0 & $\begin{array}{r}-14.4 \\
(-17.2 \text { to }-11.5)\end{array}$ & - & - & 42.1 & $\begin{array}{r}-16.7 \\
(-20.6 \text { to }-12.8)\end{array}$ & 44.3 & $\begin{array}{r}-9.3 \\
(-12.5 \text { to }-6.1)\end{array}$ & 40.0 & $\begin{array}{r}-9.7 \\
(-12.5 \text { to }-6.8)\end{array}$ \\
\hline Percentage of hous & eholds wi & th more persons & han rooms & $($ median $=1.9 \%$ & & & & & & \\
\hline Below median & 53.4 & Ref & 57.6 & Ref & 58.4 & Ref & 51.9 & Ref & 45.8 & Ref \\
\hline At or above median & 54.1 & $\begin{array}{r}0.7 \\
(-2.7 \text { to } 4.2)\end{array}$ & 58.0 & $\begin{array}{r}0.4 \\
(-5.4 \text { to } 6.2)\end{array}$ & 56.3 & $\begin{array}{r}-2.1 \\
(-5.6 \text { to } 1.4)\end{array}$ & 51.2 & $\begin{array}{r}-0.7 \\
(-3.9 \text { to } 2.4)\end{array}$ & 42.7 & $\begin{array}{r}-3.1 \\
(-5.8 \text { to }-0.5)\end{array}$ \\
\hline
\end{tabular}

See table footnotes on the next page. 
TABLE 2. (Continued) Associations between individual components of the social vulnerability index* and vaccination coverage ${ }^{\dagger}$ among U.S. adults, overall and by urbanicity ${ }^{\S}\left(\mathrm{N}=3,129\right.$ counties $\left.^{\natural}\right)$ - United States, December 14, 2020-May 1, 2021

\begin{tabular}{|c|c|c|c|c|c|c|c|c|c|c|}
\hline \multirow[b]{3}{*}{$\begin{array}{l}\text { SVI } \\
\text { indicator }\end{array}$} & \multirow{2}{*}{\multicolumn{2}{|c|}{$\begin{array}{c}\text { All } \\
\text { counties }\end{array}$}} & \multirow{2}{*}{\multicolumn{2}{|c|}{$\begin{array}{c}\begin{array}{c}\text { Large central } \\
\text { metropolitan }\end{array} \\
(n=68)\end{array}$}} & \multirow{2}{*}{\multicolumn{2}{|c|}{$\begin{array}{c}\begin{array}{c}\text { Large fringe } \\
\text { metropolitan }\end{array} \\
(n=368)\end{array}$}} & \multirow{2}{*}{\multicolumn{2}{|c|}{$\begin{array}{c}\begin{array}{c}\text { Medium and small } \\
\text { metropolitan }\end{array} \\
(n=727) \\
\end{array}$}} & \multirow{2}{*}{\multicolumn{2}{|c|}{$\begin{array}{c}\text { Nonmetropolitan } \\
(n=1,966)\end{array}$}} \\
\hline & & & & & & & & & & \\
\hline & $\begin{array}{c}\text { VC } \\
\text { estimate }\end{array}$ & $\begin{array}{c}\text { VC differences } \\
(95 \% \mathrm{Cl})\end{array}$ & $\begin{array}{c}\text { VC } \\
\text { estimate }\end{array}$ & $\begin{array}{l}\text { VC differences } \\
(95 \% \mathrm{Cl})\end{array}$ & $\begin{array}{c}\text { VC } \\
\text { estimate }\end{array}$ & $\begin{array}{l}\text { VC differences } \\
(95 \% \mathrm{Cl})\end{array}$ & $\begin{array}{c}\text { VC } \\
\text { estimate }\end{array}$ & $\begin{array}{l}\text { VC differences } \\
(95 \% \mathrm{Cl})\end{array}$ & $\begin{array}{c}\mathrm{VC} \\
\text { estimate }\end{array}$ & $\begin{array}{l}\text { VC differences } \\
(95 \% \mathrm{Cl})\end{array}$ \\
\hline \multicolumn{11}{|c|}{ Percentage of households with no vehicle access (median $=5.7 \%$ ) } \\
\hline Below median & 53.7 & Ref & 63.9 & Ref & 55.9 & Ref & 50.3 & Ref & 44.6 & Ref \\
\hline At or above median & 54.0 & $\begin{array}{r}0.3 \\
(-3.0 \text { to } 3.5)\end{array}$ & 56.7 & $\begin{array}{r}-7.2 \\
(-12.5 \text { to }-1.9)\end{array}$ & 59.3 & $\begin{array}{r}3.4 \\
(0.0 \text { to } 6.8)\end{array}$ & 52.1 & $\begin{array}{r}1.8 \\
(-2.2 \text { to } 5.8)\end{array}$ & 43.8 & $\begin{array}{r}-0.8 \\
(-3.4 \text { to } 1.7)\end{array}$ \\
\hline \multicolumn{11}{|c|}{ Percentage of persons living in institutionalized group quarters (median $=2.0 \%$ ) } \\
\hline Below median & 53.5 & Ref & 56.0 & Ref & 56.3 & Ref & 50.5 & Ref & 43.5 & Ref \\
\hline At or above median & 54.3 & $\begin{array}{r}0.9 \\
(-1.2 \text { to } 2.9)\end{array}$ & 61.4 & $\begin{array}{r}5.4 \\
(0.4 \text { to } 10.5)\end{array}$ & 58.9 & $\begin{array}{r}2.6 \\
(-2.6 \text { to } 7.8)\end{array}$ & 52.0 & $\begin{array}{r}1.6 \\
(-1.5 \text { to } 4.7)\end{array}$ & 44.6 & $\begin{array}{r}1.1 \\
(-0.9 \text { to } 3.0)\end{array}$ \\
\hline
\end{tabular}

Abbreviation: $\mathrm{Cl}=$ confidence interval; $\mathrm{Ref}=$ referent group; $\mathrm{SVI}=$ social vulnerability index; $\mathrm{VC}=$ vaccination coverage.

* Scores for all SVI measures represent percentile ranks by county ranging from 0-1 with higher scores indicating higher vulnerability. Scores were categorized into quartiles based on distribution among all 3,142 U.S. counties and then applied to the 3,129 assessed counties.

+ Vaccination coverage ( $\geq 1$ dose) was calculated by summing the number of vaccinated adults in each SVI category and dividing by the total adult population in the specified SVI category. $95 \%$ Cls for the vaccination coverage differences were calculated using generalized estimating equation models with robust standard errors to account for state variability.

§ Urbanicity categories were based on the 2013 National Center for Health Statistics urban-rural classification scheme (https://www.cdc.gov/nchs/data/series/sr_02/ sr02_166.pdf). Categories were collapsed into large metropolitan, large fringe metropolitan, medium and small metropolitan, and nonmetropolitan (micropolitan and noncore) counties.

" California counties with populations $<20,000(n=8)$ and all Hawaii counties $(n=5)$ were excluded because of lack of available county-level vaccination data.

** Results were suppressed for SVI and urbanicity categories with four or fewer counties; reference group was the lowest vulnerability quartile with more than four counties.

county-level differences related to racial and ethnic minority residents and housing types, individual SVI components suggested disparities among adults living in counties with particular housing characteristics (e.g., lower coverage in counties with higher percentages of mobile homes). These results underscore the importance of timely strategies to ensure that all communities can equitably benefit from COVID-19 vaccination.

Although differences in coverage by SVI were observed in counties of all urbanicity levels, large fringe metropolitan and nonmetropolitan counties were most affected. Persons living in these counties might experience unique challenges in accessing vaccination. For example, residents of large fringe metropolitan counties might face socioeconomic challenges, including substantial barriers to accessing health care services $(6,7)$. COVID-19 vaccination coverage has been lower in rural than in urban areas, and persons in rural areas are more likely to travel outside their county of residence for vaccination (8). Efforts to improve vaccination coverage could focus on areas that are more vulnerable with respect to socioeconomics and household composition, while tailoring interventions by urbanicity.

Focused efforts to increase access to vaccination could help ensure high and equitable vaccination coverage. Opportunities to increase access by enrolling providers who are known and trusted in the community and partnering with communityand faith-based organizations to organize pop-up clinics***

\footnotetext{
*** Pop-up clinics can operate from any publicly accessible space, and be staffed by physicians, nurses, and volunteers. https://www.cdc.gov/vaccines/ covid-19/downloads/Key-Op-Considerations-COVID-Mass-Vax.pdf
}

should be considered. Mobile and walk-in vaccination clinics with flexible evening and weekend hours could also increase access in such communities. ${ }^{\dagger \dagger}$ Home visits, although resourceintensive, have proven effective at increasing non-COVID-19 vaccination coverage among adults (9). Establishing COVID-19 vaccination clinics near child care facilities and schools, with hours communicated to parents through school channels, could increase vaccination coverage among adults in single-parent households. Vaccination locations should be accessible to persons with disabilities and offer special hours for persons who require extra assistance.

Because U.S. adults with less education and income and without health insurance were more likely to report vaccine hesitancy before the start of the COVID-19 vaccination program (10), strategies to improve vaccination coverage in counties with high SVI should also address vaccine confidence. This might include involving trusted messengers from the community who can communicate vaccine concerns, such as vaccine side effects or risk, and promote the benefit of immunization using local communication platforms. ${ }^{\$ \$ \$}$ For example, expanded public health messaging campaigns in a variety of accessible formats could raise awareness that the vaccine is free, safe, effective, and necessary to decrease COVID-19 incidence in local communities.

The findings in this report are subject to at least four limitations. First, because SVI and vaccination coverage might have

\footnotetext{
††† https://www.cdc.gov/vaccines/covid-19/planning/mobile.html $\$ \$ \$$ https://www.cdc.gov/vaccines/covid-19/vaccinate-with-confidence.html
} 
varied within counties, additional analyses could account for a finer geographic scale. Second, disparities in coverage by SVI might have differed if vaccination series completion had been assessed. Third, sparse data for certain SVI and urbanicity categories limited interpretation of results. Finally, the findings provide only a national picture of COVID-19 vaccination coverage by SVI, and state-specific patterns should be explored to direct efforts to local areas.

COVID-19 vaccination coverage disparities by SVI have persisted and increased over time, even as vaccination eligibility and access have expanded. Disparities are associated with socioeconomic status and household composition and disability, particularly in large fringe metropolitan areas. Ensuring equitable COVID-19 vaccine access will require focused efforts on increasing coverage in counties with high SVI and tailoring efforts to local population needs. Efforts could include walkin vaccination clinics and public health messaging about the importance of getting vaccinated.

\section{Acknowledgments}

Immunization program managers; immunization information system managers; other staff members of the immunization programs in the jurisdictions and federal entities; Kevin Delaney, CDC; Eli S. Rosenberg, University of Albany; CDC COVID-19 Vaccine Task Force.

Corresponding author: Vaughn Barry, vbarry@cdc.gov.

\footnotetext{
${ }^{1}$ Epidemic Intelligence Service, CDC; ${ }^{2}$ CDC COVID-19 Response Team; ${ }^{3}$ Geospatial Research, Analysis, and Services Program, Agency for Toxic Substances and Disease Registry, Atlanta, Georgia; ${ }^{4}$ Division of Population Health, National Center for Chronic Disease Prevention and Health Promotion, CDC.

All authors have completed and submitted the International Committee of Medical Journal Editors form for disclosure of potential conflicts of interest. No potential conflicts of interest were disclosed.
}

\section{References}

1. Hughes MM, Wang A, Grossman MK, et al. County-level COVID-19 vaccination coverage and social vulnerability-United States, December 14, 2020-March 1, 2021. MMWR Morb Mortal Wkly Rep 2021;70:431-6. PMID:33764963 https://doi.org/10.15585/mmwr. $\mathrm{mm} 7012 \mathrm{e} 1$

2. Agency for Toxic Substances and Disease Registry. CDC/ATSDR social vulnerability index. Atlanta, GA: US Department of Health and Human Services, CDC and Agency for Toxic Substances and Disease Registry; 2021. https://www.atsdr.cdc.gov/placeandhealth/svi/index.html

3. Flanagan BE, Hallisey EJ, Adams E, Lavery A. Measuring community vulnerability to natural and anthropogenic hazards: the Centers for Disease Control and Prevention's social vulnerability index. J Environ Health 2018;80:34-6. PMID:32327766

4. Dasgupta S, Bowen VB, Leidner A, et al. Association between social vulnerability and a county's risk for becoming a COVID-19 hotspotUnited States, June 1-July 25, 2021. MMWR Morb Mortal Wkly Rep 2020;69:1535-41. PMID:33090977 https://doi.org/10.15585/mmwr. mm6942a3

5. Office of the President of the United States. National strategy for the COVID-19 response and pandemic preparedness. Washington, DC: White House; 2021. https://www.whitehouse.gov/wp-content/ uploads/2021/01/National-Strategy-for-the-COVID-19-Response-andPandemic-Preparedness.pdf

6. Ingram DD, Franco SJ; National Center for Health Statistics. 2013 NCHS urban-rural classification scheme for counties. Vital Health Stat 2 2014;166:1-73. PMID:24776070

7. Schnake-Mahl AS, Sommers BD. Health care in the suburbs: an analysis of suburban poverty and health care access. Health Aff (Millwood) 2017;36:1777-85. PMID:28971923 https://doi.org/10.1377/ hlthaff.2017.0545

8. Murthy BP, Sterrett N, Weller D, et al. Disparities in COVID-19 vaccinations in urban versus rural counties-United States, December 14, 2020-April 10, 2021. MMWR Morb Mortal Wkly Rep 2021;70:759-64. PMID:34014911 https://doi.org/10.15585/mmwr.mm7020e3

9. Community Preventive Services Task Force. The guide to community preventive services: what works to promote health? Atlanta, GA: US Department of Health and Human Services, CDC; 2018. https://www. thecommunityguide.org/

10. Nguyen KH, Srivastav A, Razzaghi H, et al. COVID-19 vaccination intent, perceptions, and reasons for not vaccinating among groups prioritized for early vaccination-United States, September and December 2020. MMWR Morb Mortal Wkly Rep 2021;70:217-22. PMID:33571174 https://doi.org/10.15585/mmwr.mm7006e3 